\section{Determination of Injurious Phosphorus Levels in Poinsettias}

\author{
Brian E. Whipker and P. Allen Hammer \\ Department of Horticulture, 1165 Horticulture Building, Purdue University, \\ West Lafayette, IN 47907-1165
}

\section{Additional index words. Euphorbia pulcherrima}

Abstract. Eight poinsettia (Euphorbia pulcherrima Wind.) cultivars ('Angelika White', 'Celebrate 2', 'Dark Red Hegg', 'Jingle Bells 3', 'Pink Peppermint', 'Red Sails', 'Supjibi', and 'V-14 Glory') were grown in root medium amended with six triple superphosphate rates of $0.39,0.78,1.55,3.11,4.66$, and $6.21 \mathrm{~kg} \mathrm{P} / \mathrm{m}^{3}$. Root medium and foliar samples of 'Supjibi' and 'Celebrate 2' were sampled every 4 weeks, starting with the beginning of short days. At flowering, all eight cultivars were measured for diameter of the two largest bracts, number of bracts with burn, and plant height. Foliar P levels increased over the growing season for 'Supjibi' with a reading of $0.9 \%$ at anthesis, but for 'Celebrate 2', levels peaked 4 weeks before anthesis $(0.8 \%)$. At triple superphosphate rates $>3.11 \mathrm{kgP} / \mathrm{m}^{3}$, plant height decreased, and there was a significant cultivar $\times$ treatment interaction for decreased bract diameter. The eight cultivars exhibited varying degrees of susceptibilities to bract-edge burn as the amount of $P$ applied to the root medium increased, with 'Dark Red Hegg', 'V-14 Glory', and 'Red Sails' having the highest burn incidence.

In many areas where floricultural crops are grown, alkaline irrigation water may gradually raise the root medium $\mathrm{pH}$, leading to nutrient deficiencies or toxicities in plants. Acidifying the irrigation water with phosphoric acid is a common practice used to neutralize bicarbonates and maintain a proper root medium $\mathrm{pH}$ for plant growth

General recommendations for poinsettias during the growing season suggest that a preplant application of $\mathrm{P}$ be incorporated into the medium and 20 to $50 \mathrm{ppm} \mathrm{P}$ be injected into the irrigation water as a constant feed for optimal growth (Berghage et al., 1987). With the addition of phosphoric acid to modify the irrigation-water $\mathrm{pH}, \mathrm{P}$ is often supplied in excess of the recommended rate. Applying $\mathrm{P}$ $>200$ ppm with each irrigation caused phytotoxicity in geraniums $($ Pelargonium $\times$ hortorum Bailey) (Payne, 1975). In addition, excess P fertilization leads to a marked reduction in plant growth (Bingham, 1963), reduced uptake of $\mathrm{Cu}, \mathrm{B}$, andZn, and enhanced $\mathrm{Mn}$ and Mo uptake (Bingham, 1963; Bingham and Garber, 1960; Haber and Kocialkowski, 1979; Murphy et al., 1981), but results have varied with crop, root medium $\mathrm{pH}, \mathrm{P}$ placement, and growing conditions. The purpose of this study was to determine the effects of $P$ rates on plant growth and development and macronutrient $(\mathrm{N}, \mathrm{P}$, and $\mathrm{K})$ content of poinsettia leaves.

Received for publication 1 Mar. 1993. Accepted for publication 30 Aug. 1993. Paper no. 13707 of the Agricultural Experiment Station of Purdue Univ., West Lafayette, Ind. Thanks to the Fred C. Gloeckner Foundation for want support and the Paul Ecke Poinsettia Ranch for supplying the plant material. The cost of publishing this paper was defrayed in part by the payment of page charges, Under postal regulations, this paper therefore must be hereby marked advertisement solely to indicate this fact. various $P$ rates, applied as triple superphosphate. trace elements no. 555, per cubic meter of medium. The root medium was further amended with triple superphosphate $(20 \% \mathrm{P})$ at $0.39,0.78,1.55,3.11,4.66$, and $6.21 \mathrm{kgP} /$ $\mathrm{m}^{3}$. The plants were fertilized at each watering with $200 \mathrm{mg} \cdot$ liter $^{-1}$ each of $\mathrm{N}$ and $\mathrm{K}$ supplied from $517 \mathrm{mg} \mathrm{KNO} /$ liter and $367 \mathrm{mg} \mathrm{NH}_{4} \mathrm{NO}_{3} /$ liter, with $46 \mathrm{mg}$ P/liter supplied via $75 \%$ technical grade phosphoric acid in the irrigation system. Two weeks after potting, the terminal growth was pinched, leaving five nodes. After two additional weeks, plants were subjected to 16-h nights under black cloth to induce flowering.

'Supjibi' and 'Celebrate 2' plants were sampled ever-y 4 weeks, starting with the beginning of short days on 2 July. From each plant, core samples of the root medium and foliar samples of the most recently matured leaves were taken. The root medium was analyzed for $\mathrm{pH}$, soluble salts concentration, $\mathrm{NO}_{3}-\mathrm{N}$ (using a specific ion electrode), $\mathrm{P}$ with a modified Murphy-Riley procedure (Murphy and Riley, 1962), K by flame emission using a Varian SpectrAA-10 spectrometer (Varian Techtron, Mulgrave, Victoria, Australia), and $\mathrm{NH}_{4}-\mathrm{N}$ by the Nessler method (Jackson, 1958). Foliar-tissue samples were air-dried in a forcedair oven at $60 \mathrm{C}$ and ground in a Wiley mill to pass through a 20 -mesh screen. Ground tissue samples $(100 \mathrm{mg})$ were digested in a perchloric acid- $\mathrm{H}_{2} \mathrm{O}_{2}$ mixture (Adler and Wilcox, 1985) and analyzed for $\mathrm{NH}_{4}-\mathrm{N}, \mathrm{P}$, and $\mathrm{K}$ by the methods listed above. At flowering, on 28 Aug., plant height, the diameter of the two largest bracts, and number of bracts with margin bum were recorded for all eight cultivars.

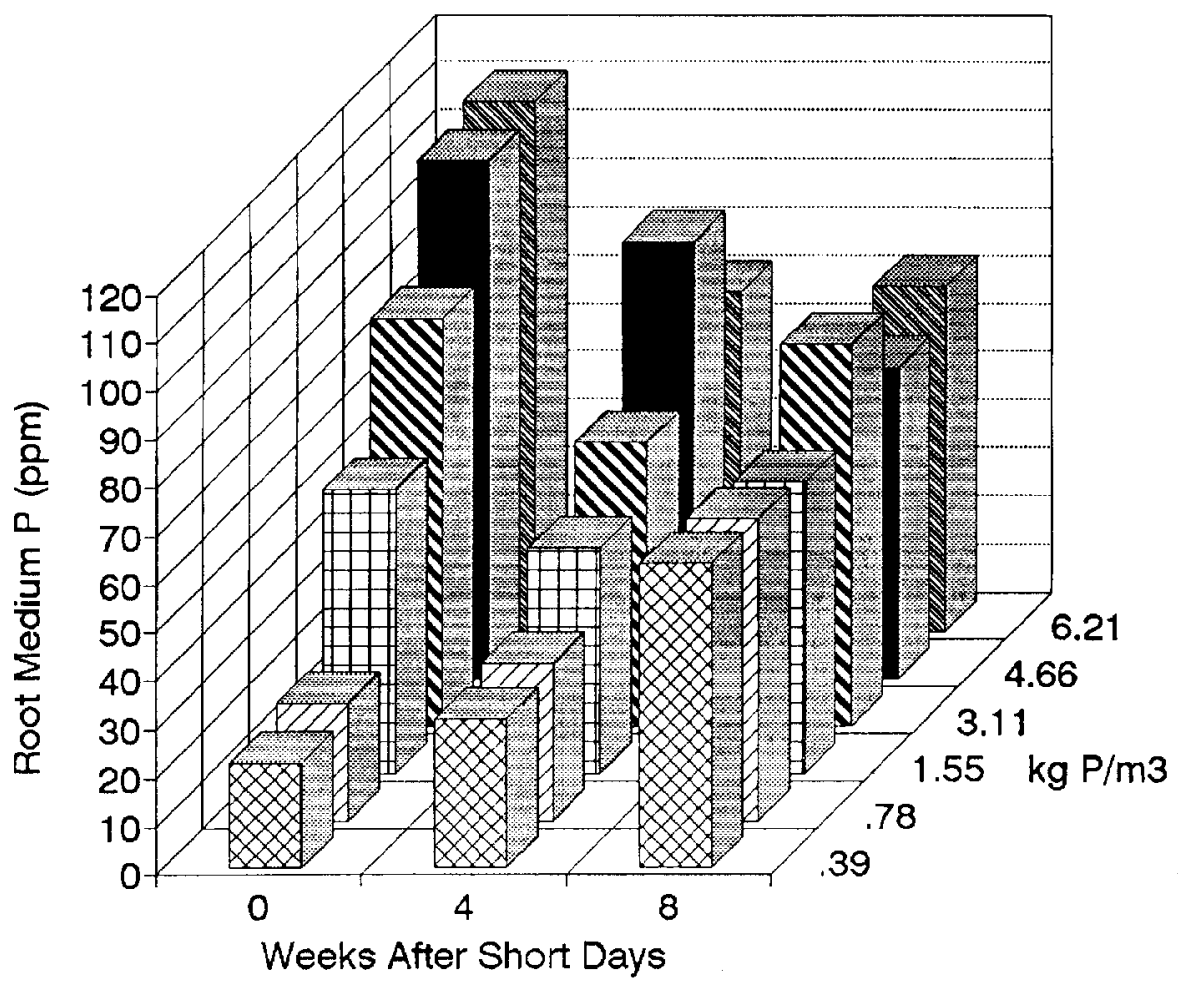

Fig. 1. Root medium P concentrations averaged over time for 'Celebrate 2' and 'Supjibi' poinsettias at 
Table 1. Foliar concentrations of $\mathrm{NH}_{4}-\mathrm{N}, \mathrm{P}$, and $\mathrm{K}$ in 'Supjibi' and 'Celebrate 2' poinsettias, dry weight basis.

\begin{tabular}{|c|c|c|c|c|c|c|}
\hline \multirow[b]{3}{*}{ Week } & \multicolumn{6}{|c|}{ Cultivar } \\
\hline & \multicolumn{3}{|c|}{ Supjibi } & \multicolumn{3}{|c|}{ Celebrate 2} \\
\hline & $\mathrm{NH}_{4}-\mathrm{N}(\%)$ & $\mathrm{P}(\%)$ & $\mathrm{K}(\%)$ & $\mathrm{NH}_{4}-\mathrm{N}(\%)$ & $\mathbf{P}(\%)$ & $\mathrm{K}(\%)$ \\
\hline 0 & 4.3 & 0.5 & 3.4 & 4.6 & 0.6 & 3.5 \\
\hline 4 & 4.0 & 0.7 & 3.3 & 4.6 & 0.8 & 3.1 \\
\hline 8 & 4.8 & 0.9 & 2.8 & 4.4 & 0.7 & 2.2 \\
\hline Linear & * & $* * *$ & $* *$ & NS & $* * *$ & $* * *$ \\
\hline Quadratic & * & NS & NS & NS & $* * *$ & NS \\
\hline
\end{tabular}

${ }_{\mathrm{Ns}}, *, * *, * * *$ Nonsignificant or significant within columns at $P \leq 0.05,0.001$, or 0.0001 , respectively.

Table 2. Influence of increasing rates of triple superphosphate on plant height at week 8 (anthesis)

\begin{tabular}{lc}
\hline \hline $\mathbf{P}\left(\mathrm{kg} \cdot \mathrm{m}^{-3}\right)$ & Plant ht $(\mathrm{cm})$ \\
\hline 0.39 & 30.7 \\
0.78 & 31.3 \\
1.55 & 30.9 \\
3.11 & 30.4 \\
4.66 & 29.6 \\
6.21 & 28.2 \\
Linear & $*$ \\
Quadratic & $*$ \\
LSD $(\alpha=0.05)$ & 1.2
\end{tabular}

${ }^{2}$ No significant treatment $x$ cultivar interaction existed.

*Significant at $P \leq 0.05$.

Results and Discussion

Root medium $\mathrm{P}$ levels increased as the triple superphosphate rate increased for 'Supjibi' and 'Celebrate 2', and a significant treatment $\times$ sampling date interaction for root medium $\mathrm{P}$ was observed (Fig. 1). These $\mathrm{P}$ levels were highest at the first sampling and decreased for the second sampling for all the treatments except the lowest two rates. By the end of the study, all root medium P levels were uniformly high among treatments. The trend of decreased root medium levels between the first and second sampling likely was due to leaching of the triple superphosphate and follows similar results reported by Havis and Baker (1985) and Yeager and Barrett (1985) for media without plants. The absence of statistical differences for root medium $\mathrm{P}$ among the treatments at the final harvest probably reflects the constant application of $\mathrm{P}$ from phosphoric acid via the irrigation water.

Foliar levels of N, P, and $\mathrm{K}$ were significantly different between sampling dates for 'Supjibi', but for 'Celebrate 2', only P and K were significant between sampling dates (Table 1). With 'Supjibi', the foliar $\mathrm{N}$ level was highest at anthesis (week 8). Foliar P levels increased over the growing season for 'Supjibi', but for 'Celebrate 2', levels peaked at week 4. Foliar K decreased over the growing season for both cultivars, with 'Celebrate 2' having a greater decline. Foliar nutrient levels of N, P, and $\mathrm{K}$ were unaffected by the amount of $\mathrm{P}$ applied for 'Supjibi' or 'Celebrate 2'.

There was a greater incidence of bractedge burn for 'Celebrate 2', but not for 'Supjibi', as the amount of triple superphosphate applied increased and the difference among treatments was significant $(P \leq 0.05)$. Bract-edge bum occurred only when the triple superphosphate level was increased to eight times $\left(3.11 \mathrm{~kg} \mathrm{P} / \mathrm{m}^{3}\right)$ or more of the base rate

Triple superphosphate rates $>3.11 \mathrm{~kg} \mathrm{P} / \mathrm{m}$ decreased plant height at final harvest (Table 2). The decrease, although slight, was statistically significant. The decrease in plant height at triple superphosphate levels $>0.78 \mathrm{~kg} \mathrm{P} / \mathrm{m}^{3}$ followed similar results by Bingham (1963) who reported a reduction in plant size as the $\mathrm{P}$

The eight cultivars exhibited varying degrees of susceptibilities to effects of high $\mathrm{P}$ on bract diameter and to bract-edge bum, and both had a significant treatment $\times$ cultivar interaction. Bract diameter was most severely reduced at triple superphosphate rates $>3.11$ $\mathrm{kg} \mathrm{P} / \mathrm{m}^{3}$, but cultivar differences did exist (Fig. 2). 'Dark Red Hegg', 'V-14 Glory', and 'Red Sails' had the highest incidence of bract-edge rates increased.

bum with increasing additions of triple superphosphate (Fig. 3). Even though bract-edge bum did increase in several cultivars as the triple superphosphate rates increased, there was no significant correlation between foliar $\mathrm{P}$ levels and the incidence of bract-edge bum. Phosphorus-rate studies are needed with several sources of $\mathrm{P}$ and in which analysis is conducted for other elements in the root medium and leaves.

\section{Literature Cited}

Adler, P.R. and G.E. Wilcox. 1985. Rapid perchloric acid digest methods for analysis of major elements in plant tissues. Commun, Soil Sci. Plant Anal. 16(11):1153-1163.

Berghage, R. D., R.D. Heins, W.H. Carlson, and J. Biembaum. 1987. Poinsettia production. Michigan State Agr. Ext. Ser. Bul. E-1382,

Bingham, F. 1963. Relationship between phosphorus and micronutrients in plants, Soil Sci. Soc. Amer. Proc. 27(3):389-391.

Bingham, F. and M.J. Garber. 1960. Volubility and availability of micronutrients in relation to phosphorus fertilization. Soil Sci. Soc. Amer. Proc. 24(2):209-213.

Haber, Z. and Z. Kocialkowski. 1979. The Influence of phosphorus on copper, iron, manganese and zinc uptake by ornamental plants cultivated in peat growing media. Prace Instytutu Sadownictwa i Kwiaciarstwa. 85-94.

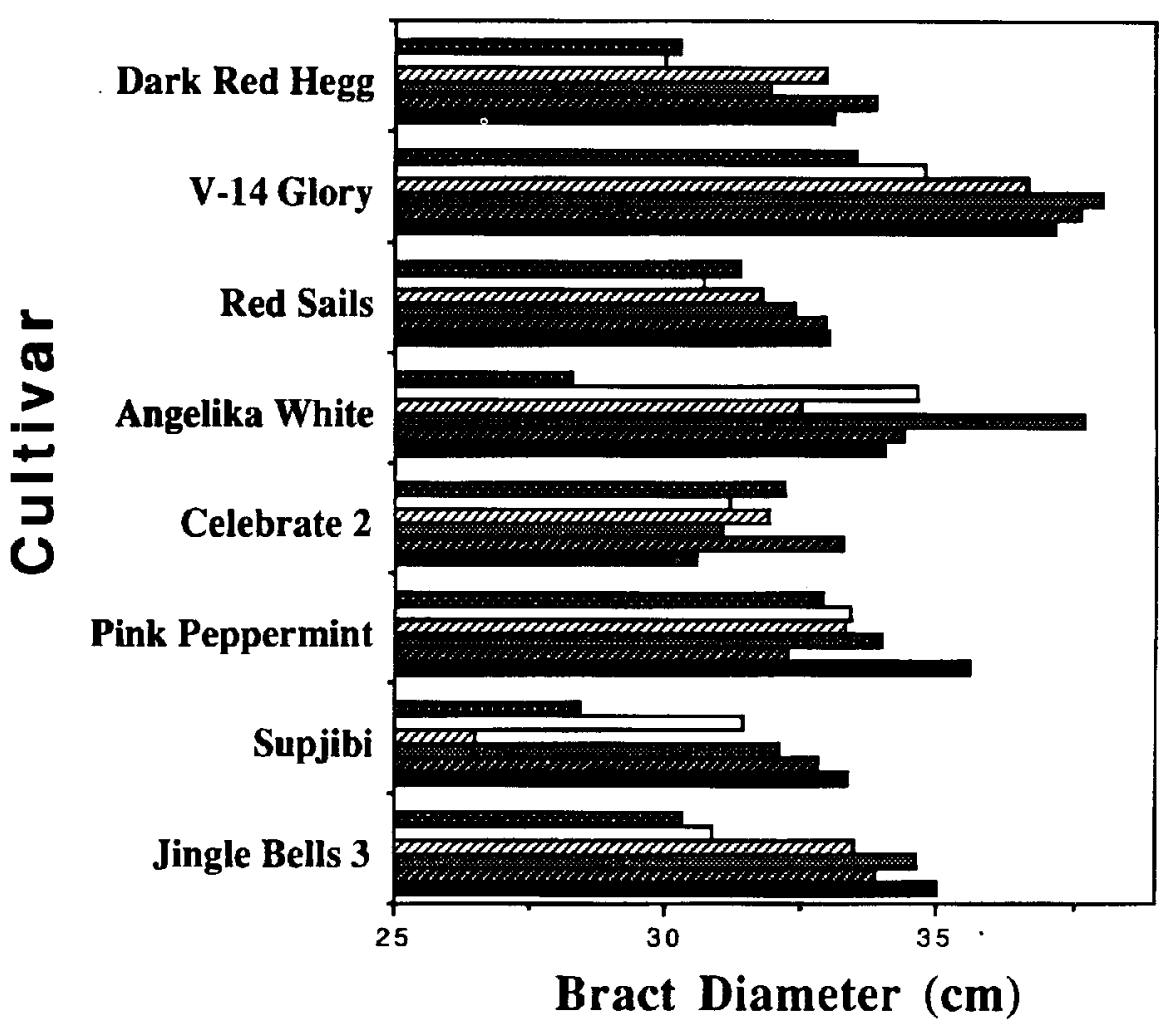

\begin{tabular}{|llll|}
\hline $6.21 \mathrm{~kg} \mathrm{P} / \mathrm{m3}$ & $1.55 \mathrm{~kg} \mathrm{P} / \mathrm{m3}$ \\
$\square$ & $4.66 \mathrm{~kg} \mathrm{P} / \mathrm{m} 3$ & $0.78 \mathrm{~kg} \mathrm{P} / \mathrm{m3}$ \\
$\square$ & $3.11 \mathrm{~kg} \mathrm{P} / \mathrm{m3}$ & $0.39 \mathrm{~kg} \mathrm{P} / \mathrm{m3}$ \\
\hline
\end{tabular}

Fig. 2. Influence of increasing rates of preplant application of triple superphosphate on bract diameter at week 8 (anthesis) of eight poinsettia cultivars. Treatment $\times$ cultivar interaction was significantly different at $\alpha=0.05$. Interaction $\mathrm{LSD}=2.16$. 


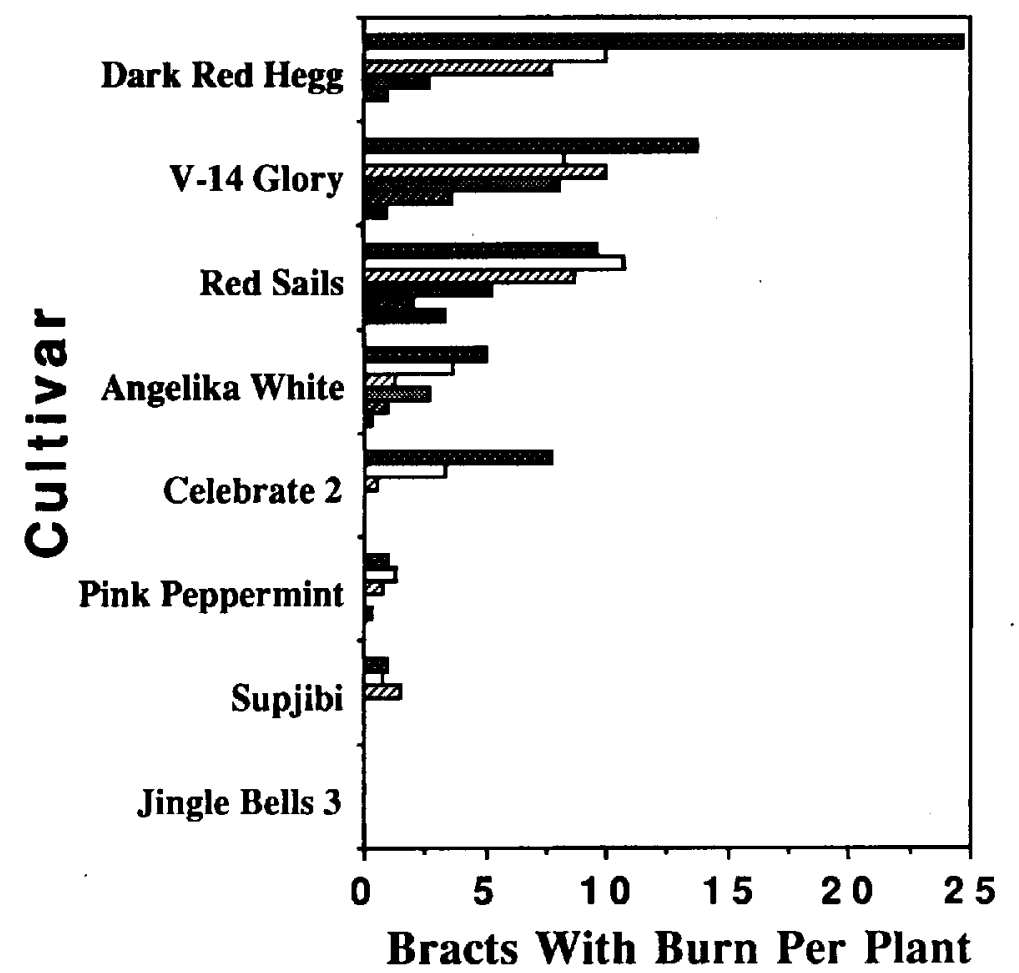

\begin{tabular}{|c|c|c|}
\hline & $6.21 \mathrm{~kg} \mathrm{P}_{\mathrm{ma3}}$ & $1.55 \mathrm{~kg} \mathrm{P} / \mathrm{m3}^{2}$ \\
\hline [ & $4.65 \mathrm{~kg}$ Phan & $0.78 \mathrm{~kg} \mathrm{P/m3}$ \\
\hline $\mathscr{Z}$ & $111 \mathrm{~kg} P / m 3$ & $0.39 \mathrm{~kg} \mathrm{P/m3}$ \\
\hline
\end{tabular}

Fig. 3. Bract-edge bum on eight poinsettia cultivars in response to preplant applications of triple superphosphate at various rates. Treatment $\times$ cultivar interaction was significantly different at $\alpha \leq 0.05$. Interaction LSD $=3.43$.
Havis, J.R. and J.H. Baker. 1985. Phosphorus availability in peat-sand media fertilized with several phosphorus sources. J. Environ. Hort. 3(4):153-155.

Jackson, M.L. 1958. Soil chemical analysis. Prentice-Hall, Englewood Cliffs, N.J.

Murphy, L. S., R, Ellis, Jr., and D.C. Adriano. 1981. Phosphorus-micronutrient interaction effects on crop production. J. Plant Nutr. 3(14):593-6 13.

Murphy, J. and J.P. Riley. 1962. A modified single solution method for the determination of phosphate in natural waters. Anal. Chim. Acta. 27:3136.

Payne, R.N. 1975. Optimizing phosphoric acid and chlormequat concentrations for growing 'Sincerity' geranium under alkaline water conditions. HortScience 10(2):175-178,

Yeager, T.H. and J.E. Barrett. 1985. Influence of incubation time on phosphorus leaching from a container medium. J. Environ. Hort. 3(4):186187. 